\title{
RACI Matrix Design for Managing Stakeholders in Project Case Study of PT. XYZ
}

\author{
Rahmad Dwi Putra Suhanda ${ }^{1 *}$, Devi Pratami ${ }^{2}$ \\ ${ }^{1,2}$ School of Industrial and System Engineering, Telkom University, Indonesia \\ Jl. Telekomunikasi Terusan Buah Batu, Bandung, 4025, INDONESIA \\ *putrasuhanda@student.telkomuniversity.ac.id
}

\section{ARTICLE INFO}

Article history:

Received 16 June 2021

Accepted 26 July 2021

Published 31 July 2021

Keywords:

Business Process;

Responsibility Assignment

Matrix; Project

Management; RACI Matrix;

\section{ABSTRACT}

Stakeholders are one of the most significant factors in the success of a project. The creation of good team performance in a project is caused by clear work responsibilities given to each project stakeholder so that stakeholders have responsibility for their work and can complete their work correctly. The responsibility assignment matrix is a method for managing the roles of each resource and describing the relationship between jobs for each job in the project, which is classified into four parts, namely Responsible, Assignment, Consult, and Informed. In this paper, a matrix will be designed to manage the work assignments of each stakeholder involved in the case of delays in project completion at PT. XYZ uses the RACI Matrix method as a guide. The results of the work assignment matrix design in the case study project of PT. XYZ shows that 12 stakeholders are grouped into four classifications according to the RACI components, which are arranged based on the level of interest and responsibility of each stakeholder to the project.

\section{Introduction}

Projects can be said to be successful when they can achieve the goals that have been set at the beginning of project planning [1]. The thing that must be done when determining a goal for a project to be carried out is by considering the quality of the project. The quality management plan is one way that can be used to outline all the activities that must be carried out by the team as well as other activities such as managing the resources needed to achieve the expected level of project quality [2]. Delay is one of the things that are not desirable in completing a project. The 85 percent of problems with project quality are caused by improper management of project resources such as teamwork systems to an inappropriate division of work responsibilities on teams [2]. Stakeholder management is critical to every project's success that can affect the result of the project [3]. Stakeholder management is one of the project managers' strategies to streamline all aspects related to their project [4]. To create a good team performance in a sustainable manner, it is necessary to have clarity of work responsibilities given to each team member so that each team member has responsibility for their own work and is able to complete their work well [5]. Stakeholder involvement can be controlled by identifying the roles of each stakeholder. Stakeholder management is focused on providing the ease of communication needed during project implementation [6].

In carrying out the project, a document is needed to facilitate the exchange of information. Communication will be successful if the sender of information is able to convey information well, which results in feedback from the recipient of the information [7]. Therefore, this study aims to redesign the matrix for managing the roles and responsibilities of stakeholders as outlined in the responsibility assignment matrix. The responsibility assignment matrix can assist the 
project owner in managing the roles and responsibilities of each project stakeholder so that the project can run according to plan. besides that, responsibility assignment matrix is a simple method, which has high flexibility, so it is very easy to use by new users and applied to projects that have an uncertain character [8].

\subsection{Objective}

The development of today increasingly digital human lifestyle also affects project life with increasing virtual media due to teams scattered in various locations, requiring project managers to communicate in different ways, one of which is virtually [9]. The increase in the use of virtual meeting applications will automatically increase the number of internet users significantly. The increase will impact the quality of the internet, which will further decline if there is no increase in infrastructure on the internet network. PT. XYZ is a company engaged in information and communication technology (ICT) services and telecommunications networks in Indonesia. In fulfilling the demands of the increasing internet needs, PT. XYZ is currently modernizing and expanding its infrastructure network. One of the projects is currently being carried out by PT. XYZ is a fiber optic feeder construction project. Fiber optic feeder is one of the network transmission media, which is one of the components of FTTH (Fiber To The Home). Fiber optic is a type of cable made of glass fiber or smooth plastic that can transmit light signals from one place to another. Fiber optic path width is larger and capable of carrying a lot of data, loading very large information with transmission speeds of up to gigabytes per second, capable of delivering long-distance information without repetition [10]. The other advantage of using fiber optic is that it has a large bandwidth capacity than copper cables and is not susceptible to interference, one of which is from electrical frequency [11].

Currently, there are projects underway, one of which is the construction of a fiber optic feeder or what is commonly known as a feederization project. This project is targeted for completion in June 2021, but in reality, this project has experienced several obstacles in its implementation, which resulted in the completion of the project not being following the plan. One of the factors that cause delays is the unclear roles and responsibilities of each stakeholder involved in the project. The following is the delay data presented in the form of an s-curve. The results of interviews that have been conducted with one of the project managers said that there were several factors causing the delay in the completion of the project, which was grouped by type. Delays based on the grouping of human resources in the project are caused by several factors such as unclear roles and responsibilities of each stakeholder, a lack of understanding of the workforce regarding the technicalities of the work being carried out, as well as supervision of suboptimal workforce performance.

\section{Literature Review}

\subsection{Resource management}

Project Resource Management is a stage in identifying, obtaining, and managing the resources needed to achieve project objectives. This stage aims to ensure that each project resource has been allocated to the right place. When resources are not managed and controlled properly, it will increase the risk that can hinder project completion [7]. There are many methods of data representation used in resource management that aim to document and communicate the roles and responsibilities of team members. In comparison, the data representation is presented in a hierarchical, matrix, or textoriented form. The other purpose of documentation is to ensure that each activity has a clear responsibility and that all team members clearly understand their roles and responsibilities [7].

\subsubsection{Outputs}

The resource management plan is something that to do during project management. The purpose is to provide guidance to the project in managing, allocating, and categorizing the project resources. The following are some human resource management plans [7].

1. Resource identification: Resource identification is a technique for identifying and considering the human resources needed for a project.

2. Roles and responsibility such as:

a. Role: The role is the behavior expected of someone who holds the status

b. Authority: The authority is a right to act owned by human resources on the project

c. Competence: Competence is a skill that must have by every human resource involved in the project

d. Responsibility: The responsibility is something that has to be completed by every person involved in the project.

\subsection{RACI Matrix}

Responsible, Accountable, Consulted, Informed (RACI), or often called the Responsibility Assignment Matrix (RAM), is a helpful tool for describing the work responsibility assignment matrix. RACI Matrix can manage the assignment of resources for each job on the project. The RACI Matrix is usually used to describe the relationship between jobs, determine the roles, responsibilities, and levels of authority for each activity in the project. [7]. Responsible, Accountable, 
Consulted, Informed (RACI) has a very strong influence because this matrix can provide ease of communication between the project manager and his team in determining their role in the project [8]. According to [12] Responsible, Accountable, Consulted, Informed (RACI) also has several other benefits, such as:

1. Make team communication easy

RACI makes it easy for team members involved in the project to communicate. With this method, the tasks for each team are clearly defined so that communication between team members is easier to do because each team already knows the role they are playing.

2. Set the number of teams in one task

The RACI matrix can determine who is the most suitable in carrying out a task according to the position held by the candidate in charge. Thus, an effective division of roles is easy to do using the RACI Matrix so that there is no excess of people in certain positions.

3. Adjust the proportion of workload.

RACI also provides benefits in managing the proportion of workload for each team member not to experience overload. When someone does too much work, it will certainly result in less than optimal performance, so that employees are at risk for experiencing stress at work caused by high workload pressure. By using RACI Matrix, each team member will be positioned according to his ability.

RACI functions as a baseline for the communication plan by determining who receives information, how often, and at what level of detail. The RACI Matrix must be defined at the final stage of the planning phase, which will later be included in the Project Charter. The definition of the RACI matrix method can be seen below.

1. Responsible

Provides information that the team member is the person who is responsible for carrying out a task until it is completed.

2. Accountable

It is information that members of this team are responsible for all tasks delegated to team members. This person also has the authority to make decisions regarding the assignment. This role is crucial because this person is responsible for every decision he has made.

3. Consulted

Those who get this role have expertise in their field because they will be in charge of providing information on the project being worked on.

4. Informed

Those who get this role is always informed of the progress of a project that is being carried out. Any changes and the results of decisions taken must be notified to someone who has this role.

\section{Methodology}

Based on the research objective, which is to design an assignment matrix for each stakeholder involved in the PT. XYZ, the RACI Matrix method, is used for the solution.

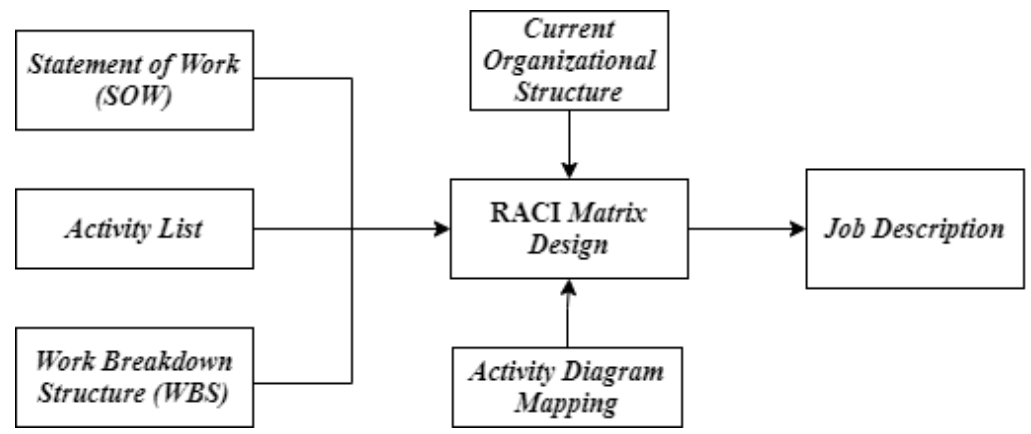

Fig. 1 - Conceptual Model

The conceptual model is a framework that shows the relationship between several ideas to solve a problem. Conceptual models can explain the relationship between these concepts [13]. Based on the conceptual model in Figure 1 above, it can be seen how the relationship between each data in this research process in designing the RACI Matrix. At the initial stage, identifying and collecting project data is carried out and describes the activities carried out on the project following 
the work breakdown structure (WBS), which will be a reference in designing the business process. Based on the business process results, an assignment matrix is determined using the RACI Matrix, which will result in the roles and responsibilities of each stakeholder involved in the project. The data collected includes the project stakeholder list, project organizational structure, work breakdown structure, and project activity list. Furthermore, data processing will be carried out starting with analyzing business process documents for each job description on the project, which will later be followed by designing an assignment matrix using the RACI Matrix Method.

\section{Data Collection}

At this stage, the data collection process needed in this research will be carried out, which will then be processed to obtain the research results. The following are supporting data in this study.

\subsection{Statement of Work}

The statement of work (SOW) is a detailed narrative description of all the work to be done on the project. The document clarifies the project description to be undertaken so that prospective vendors or stakeholders who will complete the project can decide whether they can complete the project [14]. The following is a statement of work for the PT.XYZ project.

\section{Project Owner}

The project owner of feederization project is $\mathrm{PT}$. XYZ

2. Company Profile.

PT. XYZ is a company engaged in telecommunications services that provide internet network services to meet the needs of its customers. With the increasing use of the internet, the impact of increasing customer demand in the use of services from PT. XYZ. Efforts made by PT. XYZ to meet the needs of its customers, namely by increasing the capacity and quality of the internet it produces, namely by replacing copper cables into optical fiber as a more effective internet network distribution medium.

\section{Project Title}

The project title is Arengka STO Fiber Optic Feeder Development

4. Project Places

The project location is across 7 points in the STO Arengka area, Pekanbaru Riau

\section{Project Duration}

The project duration starts in February 2021 to June 2021.

\section{Project Description}

The feederization project aims to increase the slot capacity in the Optical Distribution Cabinet, which will be connected to the Optical Distribution Point. This project aims to increase the number of users of internet services offered with good quality internet.

\subsection{Work Breakdown Structure}

Work Breakdown Structure, better known as WBS, is a hierarchy of all the work that must be done by the teams involved in the project to be completed so that the objectives of the project can be achieved [7]. WBS is one of the things needed in project management to provide clarity of work in each project scope broken down into work packages [2]. The following is a WBS from a case study of the PT.XYZ project.

Based on the work breakdown structure in Figure 2. This shows that the case study of the PT. XYZ divides its project work into two stages of work, namely the feeder tracking stage and the ODC development stage.

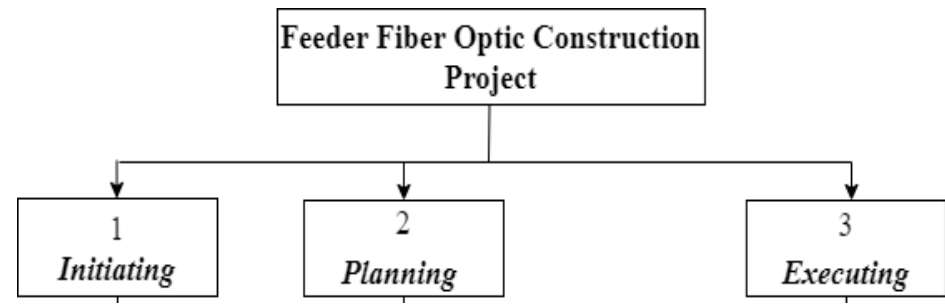

Fig. 2 - Work Breakdown Structure 


\subsection{Stakeholders Register}

Stakeholder Register is a document used for project management in identifying, assessing, and classifying stakeholders involved in the project. The Stakeholder Register can provide an overview of the role of each. The stakeholder register for the PT. XYZ will be shown in the Table 1 as follow:

Table 1 - Stakeholder Register

\begin{tabular}{ccc}
\hline No & Stakeholders & Stakeholders Classification \\
\hline 1 & Manager & Internal \\
2 & Manager Assistant & Internal \\
3 & Site Coordinator & Internal \\
4 & Asset Manager & External \\
5 & Vendor & External \\
6 & Work Member & External \\
7 & City government & External \\
8 & Urban Village & External \\
9 & Neighborhood and Hamlet & External \\
10 & Land owner or community & External \\
\hline
\end{tabular}

Based on the stakeholder register table as shown in Table 1. We know that there are several stakeholders involved in the case study of PT. XYZ. The stakeholders involved from the project owner point of view are called internal stakeholders, namely Manager, Manager Assistant, Site Coordinator. Meanwhile, stakeholders who are working partners of the project owner are referred to as external stakeholders, namely Asset Manager, Vendor, Work Member, City government, Urban Village, Neighborhood and Hamlet, Landowner or community.

\subsection{Project Organizational Structure}

Organizational structure is one of the most critical things in a project. With the organizational structure, it will be clear how the relationship between the team in the project or the relationship between different projects. It will also show the level of authority, oversight of communication lines, coordination, and collaboration of each project team. The projectized organizational structure is an organizational structure that gives the project manager great authority to have substantial control over the project and is also fully responsible for the project's success. Team members are specially assigned only to manage projects from different departments according to project requirements. This organizational structure builds a strong focus on running the project and having a good understanding of the project objectives. Large organizations often use this organizational structure to produce significant, valuable, and long-term projects [15]. The following is the project organization structure in the case study of PT. XYZ

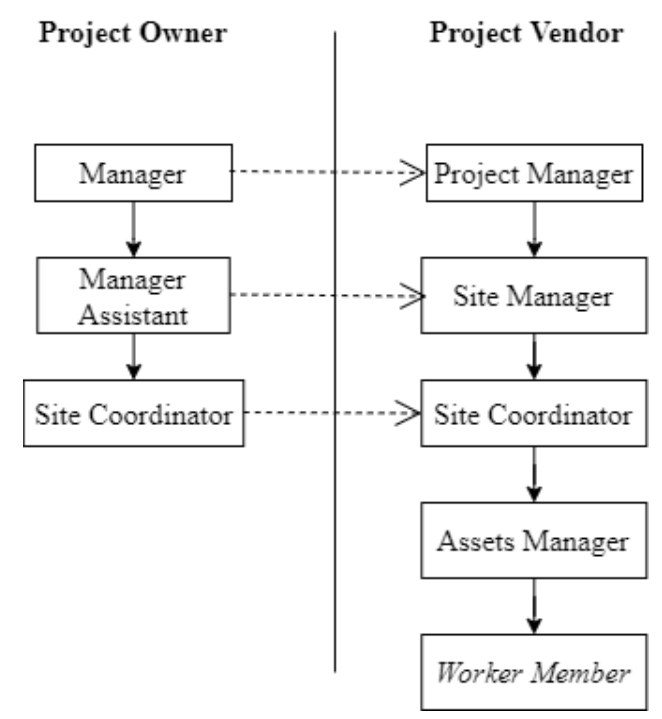

Fig. 3 - Project 


\subsection{Activity List}

Activity List is data that contains a description of the project activities. The Activity List also explains the scope of work and job descriptions for each work package in detail, making it easier for the project team to understand the work completion. Table 2 has shown the activity list for the feederization project.

Table 2 - Activity List (Part-1)

\begin{tabular}{|c|c|c|}
\hline No & Job description & Activity List \\
\hline 1 & Government Licensing & $\begin{array}{l}\text { 1. The field supervisor completes the requirements in applying for a city } \\
\text { government permit. } \\
\text { 2. Submit the required documents to the relevant city government. }\end{array}$ \\
\hline 2. & $\begin{array}{l}\text { HDPE Material } \\
\text { Procurement }\end{array}$ & $\begin{array}{l}\text { Submission of phase } 1 \text { materials by the field supervisor to the Asset Manager of PT. } \\
\text { XYZ }\end{array}$ \\
\hline 3. & Manhole Construction & $\begin{array}{l}\text { 1. Carry out a land clearing for the project. } \\
\text { 2. Make a cube-shaped iron frame with a side length of } 1.5 \text { square meters as a cast } \\
\text { frame. } \\
\text { 3. To do excavating square-shaped soil. } \\
\text { 4. Install the iron frame into the hole. } \\
\text { 5. To do Installing the manhole wall castings and trimming the HDPE installation } \\
\text { grooves. } \\
\text { 6. To do casting using cast cement. } \\
\text { 7. To do tidying up the area around the construction of the manhole and closing } \\
\text { the manhole. } \\
\text { 8. Checking the work }\end{array}$ \\
\hline 4 & HDPE Installation & $\begin{array}{l}\text { 1. Installing HDPE } \\
\text { 2. Connecting HDPE } \\
\text { 3. Installing HDPE accessories (sockets, rings, etc.) } \\
\text { 4. Ensure that there are no gaps in the connection } \\
\text { 5. Ensure that the HDPE is positioned correctly. } \\
\text { 6. Check the installation results. }\end{array}$ \\
\hline
\end{tabular}

$5 \quad$ Feeder Cable Installation

1. Feeder cable withdrawal from nearest STO

2. To do Installing the feeder into the previously made HDPE pipe.

3. Provide spare or allowance on cables under certain circumstances or as a preventive measure.

4. Doing job checks.

$6 \quad$ Citizen Licensing

7 Procurement of Material

8 ODC Foundation Development
Request permission from a resident or the owner of the land where the ODC is built.

To do Submitting ODC development materials to the asset manager of PT. XYZ by the implementing supervisor.

1. Excavating for the ODC foundation

2. Install the iron frame foundation into the hole that has been dug.

3. Install the ODC buffer as high as $60 \mathrm{~cm}$ from the surface area

4. Casting the foundation hole until the mold is complete.

5. To do installing a black ceramic floor on the ODC leg. 
9

ODC Installation

10 Feeder Cable Installation
1. Installation of Dina Bolt

2. Lifting ODC to the feet

3. Locking Dina Bolt

4. Installing the grounding system

6. Checking

1. Connecting the end of the feeder cable to the pigtail

2. Install bestray into ODC

3. To do connecting feeder cable that has been linked with the pigtail to the bestray contained in the ODC.

5. Commissioning Test and Acceptance Test

\section{Graphical Results}

The following is the result of managing the assignment matrix for stakeholders involved in the PT. XYZ project. The RACI Matrix is designed into two separate parts, which are classified into two parts, namely the internal stakeholder and external stakeholders.

\section{1 Activity Diagram Document}

An activity diagram is a chart with certain symbols representing the flow of a series of work activities in detail and describing the relationship between one process and another in an activity. An activity diagram is a tool used to describe a process in detail. Activity diagrams have symbols consisting of squares, diamonds, and other shapes connected by arrows. Activity diagrams combine symbols and flow lines to describe an operation on an activity.[16]. The following is an example of a business process that has been designed for HDPE material procurement activities.

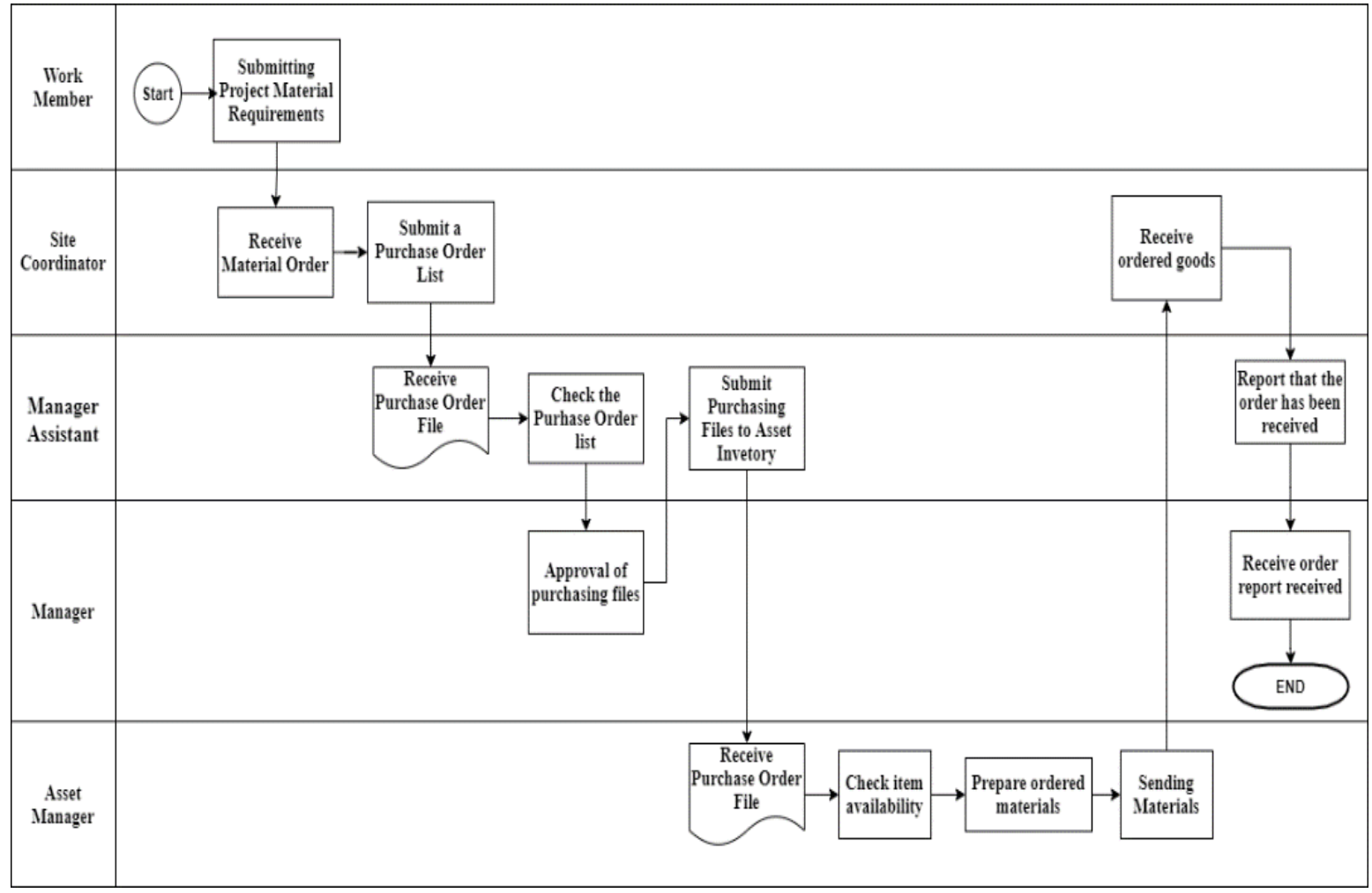

Fig. 4 - Activity Diagram of HDPE Material Delivery 


\section{2 RACI Matrix}

The following is a RACI Matrix table that has been adapted to the project business processes. Ten project activities have been adjusted to the activity list and WBS, and there are nine stakeholders involved in this case study project.

Table 4 - RACI Matrix for Internal Stakeholder

\begin{tabular}{ccccc}
\hline NO & Activity & Manager & Manager Assistant & Site Coordinator \\
\hline 1 & Government Licensing & A & C, I & R \\
2 & Citizen Licensing & A & C, I & R \\
3 & HDPE Material Procurement & A & C, I & I \\
4 & ODC Material Procurement & A & C, I & I \\
5 & Manhole Construction & A & I & C, I \\
6 & HDPE Installation & A & I & C, I \\
7 & Feeder Cable Installation & A & I & C, I \\
8 & ODC foundation development & A & I & C, I \\
9 & ODC Box Installation & A & I & C, I \\
10 & Feeder cable Installation to ODC & A & I & C, I \\
\hline
\end{tabular}

Table 4 shows the results of the preparation of the assignment matrix based on internal stakeholders from the project owner point of view. The following will show the results of the RACI Matrix design based on external stakeholders.

Table 5 - RACI Matrix for External Stakeholder

\begin{tabular}{|c|c|c|c|c|c|c|c|}
\hline NO & Activity & $\begin{array}{c}\text { Work } \\
\text { Member }\end{array}$ & $\begin{array}{c}\text { Asset } \\
\text { Manager }\end{array}$ & $\begin{array}{c}\text { City } \\
\text { Government }\end{array}$ & $\begin{array}{l}\text { Urban } \\
\text { Village }\end{array}$ & $\begin{array}{l}\text { Neighborhood } \\
\text { and Hamlet }\end{array}$ & Community \\
\hline 1 & Government Licensing & - & - & $\mathrm{I}$ & $\bar{I}$ & $\bar{I}$ & - \\
\hline 2 & Citizen Licensing & - & - & - & - & I & I \\
\hline 3 & $\begin{array}{l}\text { HDPE Material } \\
\text { Procurement }\end{array}$ & $\mathrm{R}$ & $\mathrm{I}, \mathrm{R}$ & I & - & - & - \\
\hline 4 & $\begin{array}{l}\text { ODC Material } \\
\text { Procurement }\end{array}$ & $\mathrm{R}$ & I, R & $\mathrm{I}$ & - & - & - \\
\hline 5 & Manhole Construction & $\mathrm{R}$ & - & I & I & I & I \\
\hline 6 & HDPE Installation & $\mathrm{R}$ & - & - & I & I & I \\
\hline 7 & Feeder Cable Installation & $\mathrm{R}$ & - & I & I & I & I \\
\hline 8 & $\begin{array}{l}\text { ODC foundation } \\
\text { development }\end{array}$ & $\mathrm{R}$ & - & I & $\mathrm{I}$ & I & I \\
\hline 9 & ODC Box Installation & $\mathrm{R}$ & - & I & I & I & I \\
\hline 10 & $\begin{array}{l}\text { Feeder cable Installation } \\
\text { to ODC }\end{array}$ & $\mathrm{R}$ & - & $\mathrm{I}$ & I & I & $\mathrm{I}$ \\
\hline
\end{tabular}

Based on the results of the formation of the RACI Matrix in the table. 4-5. Determination RACI Matrix elements are formed based on the roles and responsibilities of each stakeholder that has been established in the business process. As for R (Responsible) Provides information that the team member is the person who is responsible for carrying out a task that he gets to completion. A (Accountable) is information that this team member is responsible for all tasks assigned to 
his team members. This person also has the authority to make decisions related to the assignment. This role is crucial because this person is responsible for every decision he has made. $\mathrm{C}$ (Consulted) is someone who gets this role and has expertise in their field. Usually, this role is often used as a consultant on project activities. I (Informed) is a person who always gets information on the project progress being carried out, and every decision taken must be communicated to the person assigned to this role.

\section{Results Analysis}

Based on Tables 4 and 5. RACI Matrix above has formulated the roles and responsibilities for each stakeholder involved in the PT.XYZ project. The management of the work assignment matrix using the RACI Matrix method has been formed. There are nine stakeholders involved in the PT.XYZ project which is classified into four classifications according to the components in the RACI Matrix and has been adjusted to the roles and responsibilities of stakeholders sourced from business processes and activity list projects. The other method used is by observing a series of project activities and conducting interviews with several parties from the project owner and the project vendor who handles the project.

With the formation of the RACI Matrix in the PT.XYZ project, all roles, and responsibilities of each stakeholder have been clearly defined. To produce a RACI matrix that can assist project owners in managing all the roles and responsibilities of project stakeholders, it is necessary to document activity diagrams per project activity as previously mapped and the organizational structure used in the project. Furthermore, interviews with several experts involved in the feederization project are also required. If the management of previously an obstacle to project completion has been resolved, then the project can run normally as planned.

Based on the results of the preparation of the RACI Matrix in Tables and the previous data processing, it can be seen that to run the project in the PT.XYZ case study it takes five stakeholders who have important job descriptions on the project, namely Manager, Assistant Manager, Site Coordinator, Asset Manager, Work Members. The roles and responsibilities of each relevant stakeholder can be seen in the following table:

Table 6 - Stakeholder Job Description

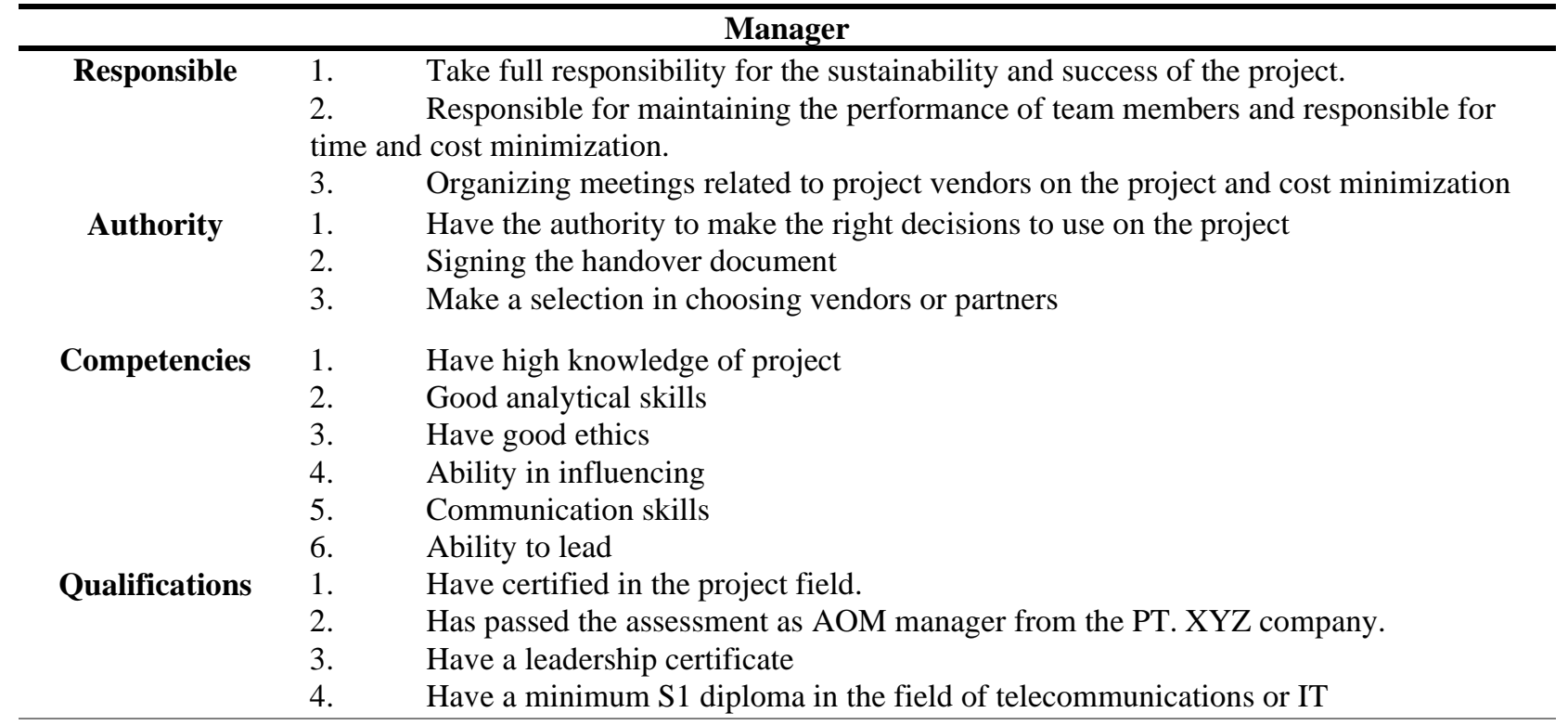




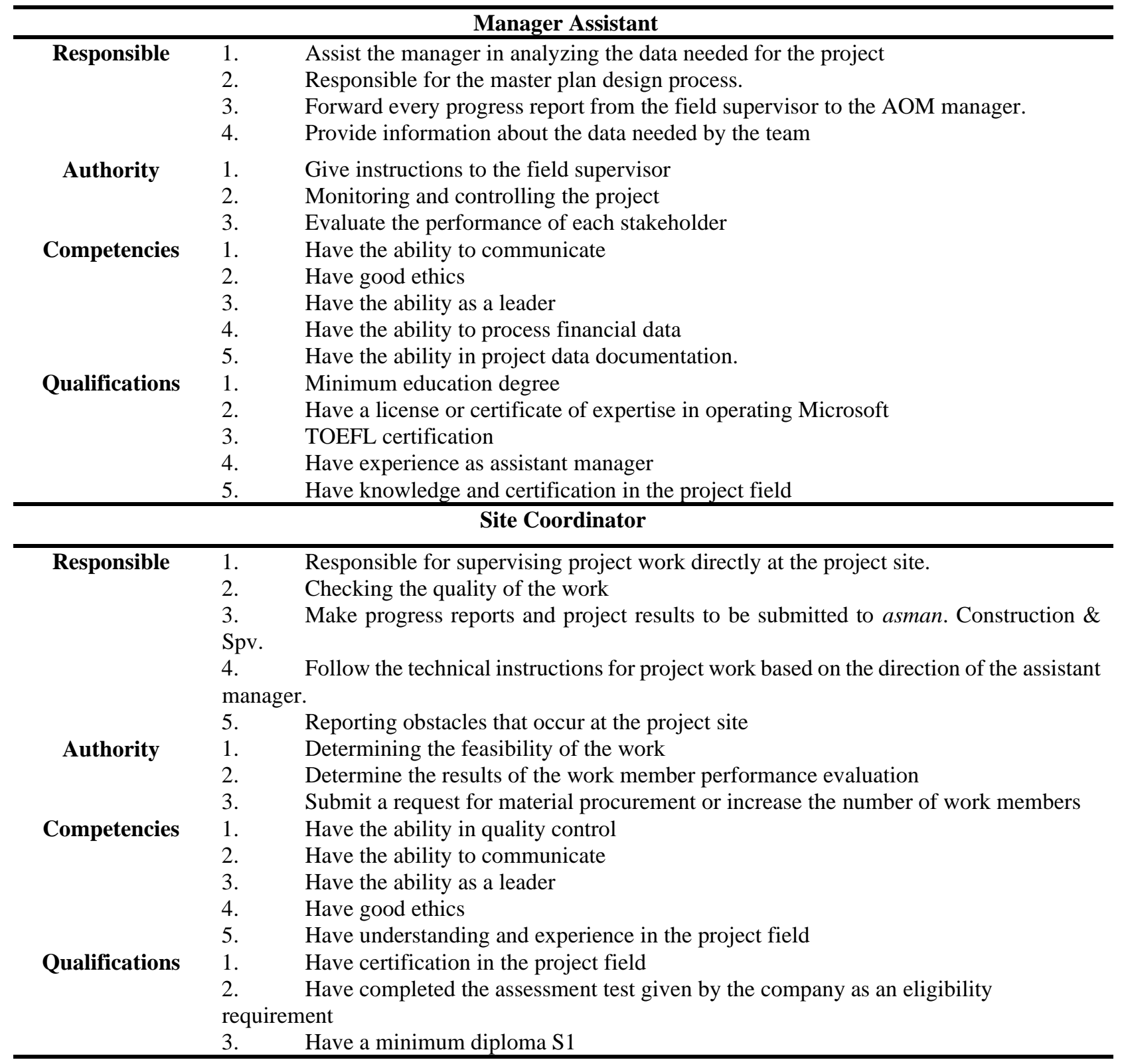

Table 7 - Stakeholder Job Description

\begin{tabular}{lll}
\hline & & \\
\hline Responsible & 1. & Rsset Manager \\
& 2. & Check the availability of goods. \\
& 3. & To do checking the quality of the material to be sent to avoid product defects. \\
& 4. & To do check the goods to be submitted to minimize material mismatches. \\
& 5. & Responsible for fulfilling all material requests. \\
Authority & 6. & Responsible for all warehouse inventory assets. \\
& 1. & Has the authority to determine the acceptance order from Asman. construction \& spv \\
& 2. & Have the authority to select logistics vendors for the material mobilization process. \\
& 3. & Has the authority to determine the right supplier in meeting material stock needs. \\
& 1. & Have high knowledge of project materials \\
& 2. & Good analytical skills \\
& 3. & Have good ethics \\
& 4. & 4bility in influencing \\
& 5. & Communication skills
\end{tabular}


6. $\quad$ Ability to lead

\begin{tabular}{|c|c|c|}
\hline Qualifications & $\begin{array}{l}1 . \\
2 . \\
3 . \\
4 .\end{array}$ & $\begin{array}{l}\text { Certified in the project field } \\
\text { Has passed the assessment as an asset manager from the PT.XYZ company } \\
\text { Have a leadership certificate } \\
\text { Have a minimum diploma of S1 in the field of telecommunications or IT }\end{array}$ \\
\hline \multicolumn{3}{|r|}{ Work Member } \\
\hline Responsible & $\begin{array}{l}1 . \\
2 . \\
3 . \\
4 .\end{array}$ & $\begin{array}{l}\text { Complete all physical work on project activities } \\
\text { Reporting the progress of the work to the field supervisor } \\
\text { Report incidents in the project area to the field supervisor } \\
\text { Propose procurement following project needs. }\end{array}$ \\
\hline Authority & & e authority to accept or reject the work contract for the next project. \\
\hline Competencies & $\begin{array}{l}1 . \\
2 . \\
3 .\end{array}$ & $\begin{array}{l}\text { Have basic skills as a construction worker (builder). } \\
\text { Have good ethics } \\
\text { Able to operate construction work equipment }\end{array}$ \\
\hline Qualifications & $\begin{array}{l}1 . \\
1 . \\
2 . \\
3 .\end{array}$ & $\begin{array}{l}\text { Have experience in working as a construction worker (builder) } \\
\text { Maximum age } 40 \text { years old } \\
\text { Physically and mentally healthy }\end{array}$ \\
\hline
\end{tabular}

\section{Conclusion}

This research concludes that the human resources on the project must be appropriately managed so that the project completion is as expected. The RACI matrix can provide convenience in managing stakeholders in this feederization project. The RACI matrix groups the roles of each stakeholder involved in the project into four components: responsible, accountable, consulted, and informed. The design of the RACI Matrix on the case study project of PT. XYZ was formed, starting with conducting interviews and identifying stakeholders involved in the PT.XYZ case study project. With the formation of the RACI Matrix, the roles and responsibilities of each stakeholder in the project will be more precise, and Job description documents can be more easily determined. The purpose of designing the RACI Matrix is to overcome the delay factor caused by the stakeholder and resource aspects, the project owner's responsibility as a decision-maker. With the RACI Matrix, it is hoped that it will facilitate communication between the project owner and all stakeholders involved in the case study of PT. XYZ and the role for each stakeholder has been well managed so that the risk of obstacles caused by resource management factors at the next project stage becomes smaller. As for suggestions that can be given to the next research, namely, to analyze the limitations and efforts at the next research object to implement RACI Matrix. As for the analysis of efforts to simplify the process of implementing the RACI Matrix on research projects, namely based on aspects of man, methods, money, machines, time.

\section{Disclaimer}

The authors whose names are written certify that they have no conflict of interest.

\section{References}

[1] M. F. Sufa, “Identifikasi Kriteria Keberhasilan Proyek,” Performa, vol. 11, no. 1, pp. 19-22, 2012.

[2] R. Mulcahy, PMP Exam Preparation 9th Edition, 9th ed. RMC Pubns Inc, 2018.

[3] D. Pratami, N. A. Puspita, and I. Haryono, "Designing Project Stakeholder Management Plan at Coffee Plant Construction Project for Sucessful Initiating Phase in Ciwidey,” Int. J. Innov. Enterp. Syst., vol. 01, no. 01, pp. 19-28, Jul. 2017, Accessed: Jun. 15, 2021. [Online]. Available: https://ijies.sie.telkomuniversity.ac.id/index.php/IJIES/article/view/6/4.

[4] J. B. Forman and R. Discenza, "Got Stake? Holder Management in Project - Stakeholder Management Plan," Oct. 2012, Accessed: May 30, 2021. [Online]. Available: https://www.pmi.org/learning/library/stakeholdermanagement-plan-6090.

[5] P. Bristol, "The brick and mortar of project success," Paper presented at PMI® Global Congress, 2012. https://www.pmi.org/learning/library/project-success-core-values-key-accountabilities-6262 (accessed Oct. 14, 2020).

[6] P. W. Ihuah, I. I. Kakulu, and D. Eaton, "A review of Critical Project Management Success Factors (CPMSF) for sustainable social housing in Nigeria," Int. J. Sustain. Built Environ., vol. 3, no. 1, pp. 62-71, Jun. 2014, doi: 10.1016/j.ijsbe.2014.08.001.

[7] PMI, A Guide to the Project Management Body of Knowledge, 6th ed. Project Management Institute, 2017. 
[8] A. S. Elhady and H. M. Abushama, "RACI Scrum Model for Controlling of Change User Requirement in Software Projects," Int. J. Appl. or Innov. Eng. Manag., vol. 4, no. 1, pp. 214-220, 2015.

[9] P. Pullan and P. Evi, "Leading Virtual Project Teams," Paper presented at PMI® Global Congress 2016EMEA, May 13, 2016. https://www.pmi.org/learning/library/leading-virtual-project-teams-10190 (accessed Dec. 19, 2020).

[10] D. Kho, "Pengertian Fiber Optik (Optical Fiber) dan Jenis-jenisnya," Komponen Elektronika, Sep. 2020. https://teknikelektronika.com/pengertian-fiber-optik-optical-fiber-jenis-jenis-fiber-optik/ (accessed Oct. 02, 2020).

[11] M. Koswara, "Benefit Of Optical Termination Premises In The Fiber To The Home Network," Elektro Telekomun. Terap., pp. 2-15, Dec. 2016.

[12] S. Haworth, "Example RACI Chart For Project Managers \& How To Make It," thedigitalprojectmanager.com, Aug. 10, 2020. https://thedigitalprojectmanager.com/raci-chart-made-simple/ (accessed Oct. 16, 2020).

[13] B. S. Yudha, I. Haryono, and L. W. Suwarsono, "Perancangan Job Description Berdasarkan Kerangka Business Process Pada Cv . Gradient Job Description Design Based on Businees Process Framework At Cv . Gradient," vol. 4, no. 2, pp. 2529-2534, 2017.

[14] D. H. Syahchari, "The Statement of Work - Management," Binus University, Dec. $11,2019$. https://bbs.binus.ac.id/management/2019/12/the-statement-of-work/ (accessed Jun. 15, 2021).

[15] J. R. San Cristóbal, V. Fernández, and E. Diaz, "An analysis of the main project organizational structures: Advantages, disadvantages, and factors affecting their selection,” Procedia Comput. Sci., vol. 138, pp. 791798, 2018, doi: 10.1016/j.procs.2018.10.103.

[16] S. F. Wamba and D. Gnanzou, "A Literature Review on Business Process Management, Business Process Reengineering, and Business Process Innovation A Literature Review on Business Process Management, Business Process Reengineering, and Business Process Innovation,” Enterp. Organ. Model. Simulation, no. June, 2013, doi: 10.1007/978-3-642-41638-5. 